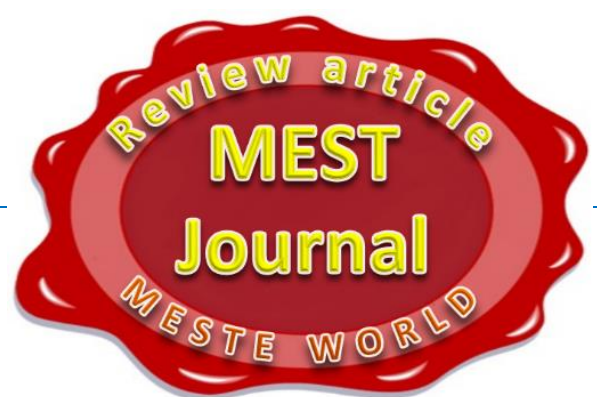

\title{
LIBERTARIAN THEORY OF BRIBERY AND INCITEMENT: A REFORMULATION
}

\section{Lukasz Dominiak}

Faculty of Political Science and International Studies, Nicolaus Copernicus University, Torun, Poland

\section{Walter E. Block}

\author{
Harold E. Wirth Eminent Scholar Endowed Chair and Professor of \\ Economics, Joseph A. Butt, S.J. College of Business, Loyola University New \\ Orleans, LA USA
}

OMESTE

JEL category: K14

\begin{abstract}
In the present paper, we propose a reformulation of the libertarian theory of bribery, particularly of Rothbard's account of the briber as an innocent inciter to crime. We discern an incompatibility between Rothbard's theories of bribery and incitement and side with the latter. This philosopher-economist maintains that only the bribee, not the briber, is guilty of criminal behavior; and also, that while incitement should be legal, aiding and abetting people into committing a crime should be considered illicit in law. But, the briber, in our view, does not merely limit himself to inciting the bribee, he actually aids and abets him. The briber exceeds the role of a mere inciter because he not only exercises his rights of free speech but also pays the bribee for violating the employment contract. Therefore, Rothbard's criterion for being merely an innocent inciter, i.e. that the inciter has nothing further to do with the criminal activities he incited others to perform, is not fulfilled in the case of the briber who also pays the bribee for the contract violation.
\end{abstract}

Keywords: Bribery; incitement; libertarianism

\section{INTRODUCTION}

A standard, Rothbardian formulation of the libertarian theory of bribery says that paying a bribe is a kind of discount on goods and services or a rebate paid by the briber to the bribee. Therefore, according to this formulation, "there is

The address of the corresponding author: Lukasz Dominiak 莑: lukasdominiak80@gmail.com nothing illegitimate about the briber" and so "there should be a property right to pay a bribe" (Rothbard 1998, p. 129).

In the present paper, we claim that this account is untenable, particularly that it contradicts the Rothbardian theory of the limits of free speech and crime. Contrary to his account, we argue that in the case of bribery which involves a violation of an employment contract on the part of the bribee, not only the bribee but also the briber commits a 
crime. To justify our position, we propose to look at bribery from the vantage point of the incitement ${ }^{1}$ to crime and particularly from the perspective of a crucial distinction between being a mere inciter on the one hand and being a person implicated in crime (a criminal) on the other. We argue therefore that Rothbardian interpretation of paying a bribe as a legitimate practice of lowering the price is unsound and inconsistent with other elements of his own theory. Abandoning this interpretation, we make a case for interpreting bribe paying as a complicity in crime on the part of the briber, viz. as a violation of property rights that should be considered illegal and punished accordingly. By making our point we hope to slightly refine an otherwise magnificent theory of Murray Rothbard's and to contribute to the advancement of the libertarian political philosophy.

In section 2 we discuss Bribery and Title-Transfer Theory of Contracts. Section 3 is given over to our analysis of Bribery and Incitement to Crime. The burden of section 4 is deal with Incitement and Complicity. In section 5 we confront Paying a Bribe as Complicity in Crime. We deal with an objection to our thesis in section 6 and conclude in the section 7 .

\section{BRIBERY AND TITLE-TRANSFER THEORY OF CONTRACTS}

Per Rothbard, there is one and only one scenario in which bribery involves illegality: when, because of a bribe which he accepts, the bribee violates the employment contract with the owner of the company he works for. Rothbard writes (1998, p. 129):

"Suppose that Black wants to sell materials to the XYZ Company. In order to gain the sale, he pays a bribe to Green, the purchasing agent of the company. It is difficult to see what Black has done which libertarian law should consider as illegal. In fact, all he has done is to lower the price charged to the $X Y Z$ Company by paying a rebate to Green. From Black's point of view, he would have been just as happy to charge a lower price directly, though presumably, he did not do so because the $X Y Z$ executives would still not have purchased the materials from him. But the inner workings of the XYZ Company should scarcely be Black's responsibility. As far as he is concerned, he simply lowered his price to the Company, and thereby gained the contract. The illicit action here is, instead, solely the behavior of Green, the taker of the bribe. For Green's employment contract with his employers implicitly requires him to purchase materials to the best of his ability in the interests of his company. Instead, he violated his contract with the $X Y Z$ company by not performing as their proper agent: for because of the bribe he either bought from a firm which he would not have dealt with otherwise, or he paid a higher price than he need have by the amount of his rebate. In either case, Green violated his contract and invaded the property rights of his employers. In the case of bribes, therefore, there is nothing illegitimate about the briber, but there is much that is illegitimate about the bribe, the taker of the bribe. Legally, there should be a property right to pay a bribe, but not to take one. It is only the taker of a bribe who should be prosecuted."

Rothbard's claim finds its justification in the titletransfer theory of contracts which says that for a contract to bind, there must be a property title that one party conditionally transfers to the other party so if the other party does not fulfill his contractual obligations, he finds himself in illegitimate possession of this property. A violation of a binding contract constitutes, therefore, an implicit theft: "In short, a contract should only be enforceable when the failure to fulfill it is an implicit theft of property. But this can only be true if we hold that validly enforceable contracts only exist where title to property has already been transferred, and therefore where the failure to abide by the contract means that the other party's property is retained by the delinquent party, without the consent of the former (implicit theft)" (1998, p. 133).

In the case of bribery, a crime committed by the bribee consists thus exactly in this implicit theft: by

\footnotetext{
${ }^{1}$ For other libertarian analyses of incitement, see Block (2011; 2012); O'Neill and Block (2013). For a debate on this matter, see Mortellaro (2009) and Block (2009).
} 
violating the employment contract, the bribee becomes an illegitimate possessor of the employer's property ${ }^{2}$. Analytically speaking, what is then a core of the bribee's crime is not the fact that he accepts a bribe and privately pockets it (there is nothing inherently wrong with accepting money or other goods from people outside the employment contract) but that he violates his employment contract, although he does it because of a bribe. It can be the case that because of a bribe the bribee favors an offer which is worse for his employer than other offers submitted to the company; it can also be the case that he favors an offer that is the best for his employer but by the very fact of accepting a bribe, the offer is then more expensive for the employer than it could have been if bribery had not occurred. This point is further supported by Rothbard's remarks on bribing the very owner of the company, in which case, "there would have been no violation of anyone's property right and therefore properly no question of illegality" (1998, p. 130). ${ }^{3}$

In the remainder of our paper, we focus exclusively on a scenario in which bribery involves illegality (viz. when because of a bribe the bribee commits an implicit theft ${ }^{4}$ by violating the employment contract) and within the purview of this scenario we scrutinize the role of the briber. ${ }^{5}$

2 In effect, the employer's money. That is to say, in the absence of this theft on the part of the bribee, the employer, the owner, of the XYZ company would have ended up with the money that Black, the briber paid to Green, the bribee. If we eliminate the "middle man" Black, then Green stole from XYZ.

3 That is to say, suppose Black bribed not Green, the employee of $X Y Z$, but the latter directly. Then, there would have been nothing untoward about the commercial interaction. We would be hard put, even, to consider this a "bribe" at all. For, what is the difference between a bribe and a voluntary payment? The former must be in at least some way, illicit, or at least questionable, while the latter is not.

${ }^{4}$ Perhaps "indirect theft" would be more accurate.

${ }^{5}$ From this point on any time we talk about bribery we mean this and only this scenario.

${ }^{6} \mathrm{We}$ could perhaps extrapolate to other contracts, although this is not usually done. Suppose Mr. Smith

\section{BRIBERY AND INCITEMENT TO CRIME}

As we pointed out above, bribery and its illegality consist in a violation of an employment ${ }^{6}$ contract by an employee (a bribee) who prefers to accept this payment than to abide by the contract. If that is the case - and we have seen that it is with no doubts the case for Rothbard - what then is the point of the potential briber's actions? The potential briber, Black, tries to persuade an employee of the $X Y Z$ company, Green, to accept his business offer even though from the point of view of Green's employer it is a worse offer than those submitted by Black's competitors. ${ }^{7}$ Black tries to persuade Green to become a bribee, i.e. to violate the employment contract and to accept Black's offer, contrary to Green's employer's best interest but to the advantage of Black, the briber. In a word, Black tries to incite Green to commit a crime: Go! Violate Contract! Implicitly Steal! Paying a bribe is, therefore, better characterized as an incitement to crime rather than as paying a rebate. ${ }^{8}$ First of all, because paying a rebate is just one amongst many possible ways of persuading a buyer to make a purchase, it can be subsumed under the general term of persuading a buyer. Second, because the specific point of persuasion in the case of bribery is to encourage an employee of a given company to commit a crime, this kind of persuasion can be specified not merely as an incitement to crime, but as actively engaging, participating, in it. ${ }^{9}$

bribes Mrs. Jones to go to bed with him. The latter has no employer from whom she can be stealing money as in the Rothbardian example. However, she does have a husband, Mr. Jones, from whom she is stealing something (maybe even money, who knows, as in the case of pimping), perhaps honor. In any case, she is violating some agreement, at least in the case of monogamous marriage.

7 Black's comparative advantage over his competitors is that he is willing to bribe Green, while they are not.

8 Both are accurate. But in the present context, we are accusing Black not of merely inciting Green to commit a crime, but of actively aiding and abetting him to do so, by paying him for this service. Block (2012) levels a similar accusation against Spike Lee.

9 The taxi driver who unwittingly and unknowingly transports the robber gang to the bank, or the restaurant that sells them lunch, and the shoe store that sells them their footwear (assuming all these 
If that were the end of the story, Rothbard's position that "there is nothing illegitimate about the briber" and so "there should be a property right to pay a bribe", would be saved, though slightly reformulated, because there is nothing wrong with inciting to crime - the inciter just enjoys his right to free speech. As Rothbard put it: "Should it be illegal, we may inquire, to 'incite to riot'? Suppose that Green exhorts a crowd: Go! Burn! Loot! Kill! And the mob proceeds to do just that, with Green having nothing further to do with these criminal activities. Since every man is free to adopt or not adopt any course of action he wishes, we cannot say that in some way Green determined the members of the mob to their criminal activities; we cannot make him, because of his exhortation, at all responsible for their crimes. 'Inciting to riot', therefore, is a pure exercise of a man's right to speak without being thereby implicated in crime" (1998, p. 81). By the same token, it seems that Black, the briber, does just this, namely exercises his freedom of speech by adding just one more cry to Rothbardian Green's exhortations: Go! Burn! Loot! Kill! Implicitly Steal! The problem is though that it is not the end of the story.

\section{INCITEMENT AND COMPLICITY}

According to Rothbard (1998, p. 81), there is a difference between merely inciting to commit a crime and actually committing one. He expresses this difference as a proviso saying that it is legal to incite to crime only as far as the inciter has "nothing further to do with these criminal activities". Within these limitations, the inciter simply enjoys his right to free speech. Otherwise and outside these boundaries he is no longer a mere inciter but a person implicated in the crime, in a word, a criminal. From Rothbard's point of view, inciting to crime "is a pure exercise of a man's right to speak without being thereby implicated in the crime. On the other hand, it is obvious that if Green happened to be involved in a plan or conspiracy with others to commit various

services are necessary for the crime), are innocent, as is Rothbard's mere inciter. But the getaway driver, the cook and the quartermaster who are all members of the gang and share in its spoils even though they do not pull any triggers, are guilty as is the person who aids and abets the mob, not only by shouting "Go! Burn! Loot! Kill!" at them, but by giving crimes, and that then Green told them to proceed, he would then be just as implicated in the crimes as are the others - more so, if he were the mastermind who headed the criminal gang. This is a seemingly subtle distinction which in practice is clear-cut - there is a world of difference between the head of the criminal gang and a soap-box orator during a riot; the former is not, properly, to be charged simply with 'incitement'" (1998, p. 81).

There is no doubt that if Green paid someone to commit a crime, Green would not be a mere inciter but would have something further to do with this crime and in this manner, would himself be a criminal. Consider the contract-killing case. If Green paid Black, a contract killer, to murder Green's wife and Black did it, Green not only incited Black to commit a crime but also and most of all contracted him to do it, i.e. he transferred a property title to his money in exchange for Black's service $^{10}$. One cannot justify a claim that Green merely said something (“Go! Kill my wife!") and had nothing further to do with the murder of his spouse, since he both said something (Go! Kill!) and paid Black to do it, which is literally a definition of "having something further to do with these criminal activities". Therefore, Green is not a mere inciter but an accomplice.

\section{PAYING A BRIBE AS COMPLICITY IN CRIME}

Having prepared grounds and crucial distinctions, we are now able to conclude our argument. As we put it above, the briber tries to incite an employee of a given company to violate an employment contract and accept the briber's offer contrary to the company's best interests. In a word, the briber tries to incite the employee to commit a crime. Unfortunately for Rothbard's position, this classification of a briber as an inciter is only a first approximation. If we look at the crucial distinction between merely inciting to crime and having something further to do with it, i.e. cooperating with others to commit a crime, we clearly see that

them an address of the target, as in the case of Spike Lee, or by paying them to do so, as does the briber in our example.

10 Of course, this contract cannot be valid on libertarian grounds, since Black does not have a right to provide Green with such a service 
the briber has crossed the border of freedom of speech and mere incitement and entered the purview of complicity in the crime. For it is obviously false that the briber has "nothing further to do with these criminal activities" that are committed by the bribee. Quite to the contrary, the briber both incites and pays the bribee to commit a crime of implicit theft - and this is literally a paradigm case of "having something further to do with these criminal activities". The briber is implicated in the crime and can be properly classified as an accomplice. The full analogy is therefore not with the mere incitement to crime, let alone with paying a rebate or lowering the price but rather with a contract killing. Green contracting Black to murder Green's wife and Green bribing Black to implicitly steal is philosophically indistinguishable: he pays an executant to commit a crime.

Hence, Rothbard's analysis of paying a bribe in terms of lowering the price is inconsistent with his theory of crime and freedom of speech, particularly with his account of the difference between inciting to crime on the one hand and being implicated in crime on the other. Consequently, his conclusions that "there is nothing illegitimate about the briber" and so "there should be a property right to pay a bribe" are untenable. What is illegitimate about the briber, is a fact that he cooperates in crime with the bribee and so there cannot be a property right to pay a bribe. Such a "right" would contradict other, true property rights. Therefore, from a libertarian point of view paying a bribe when it involves a contract violation on the part of the bribee is, contrary to what Rothbard said, a crime that should be prosecuted and punished accordingly.

\section{AN OBJECTION}

The following is a slightly edited version of a response to an earlier version of the present paper written by an eminent libertarian philosopher ${ }^{11}$ :

"I don't agree that you have come up with a valid criticism of Murray Rothbard. You are right that there is tension between holding that bribery shouldn't be illegal and holding that incitement to commit a crime should not be legal. Your mistake, as I see it, is to take Rothbard to hold that incitement should not be legal. You have misread the relevant passage from Chapter 12 of Ethics of Liberty, which is this:

"Should it be illegal, we may next inquire, to 'incite to riot'? Suppose that Green exhorts a crowd: 'Go! Burn! Loot! Kill!' and the mob proceeds to do just that, with Green having nothing further to do with these criminal activities. Since every man is free to adopt or not adopt any course of action he wishes, we cannot say that in some way Green determined the members of the mob to their criminal activities; we cannot make him, because of his exhortation, at all responsible for their crimes. 'Inciting to riot,' therefore, is a pure exercise of a man's right to speak without being thereby implicated in the crime.

"On the other hand, it is obvious that if Green happened to be involved in a plan or conspiracy with others to commit various crimes, and that then Green told them to proceed, he would then be just as implicated in the crimes as are the others - more so, if he were the mastermind who headed the criminal gang. This is a seemingly subtle distinction which in practice is clear-cut there is a world of difference between the head of a criminal gang and a soap-box orator during a riot; the former is not, properly to be charged simply with 'incitement.'

"You have wrongly taken 'Go! Burn! Loot! Kill! Implicitly Steal!' from this passage to indicate that Rothbard is in favor of making incitement illegal. In fact, as the context makes clear, he is rejecting this view."

We the present authors cannot see our way clear to agreeing with this criticism of our paper. In our view, this eminent libertarian philosopher is correct in seeing a "tension" between these two views of Rothbard, but he does not realize that this really constitutes a deep chasm, that is, a logical contradiction. Rothbard cannot be allowed to have it both ways. He may not, on the one hand, claim that while incitement should be legal ${ }^{12}$ actively taking part in a crime should not be, and on the other hand maintaining that the briber is limited to exhortation. No, the briber pays the bribee to

\footnotetext{
${ }^{11}$ Who shall remain anonymous

12 We, as libertarian followers of Rothbard
}

certainly agree with him on that. 
engage in illicit behavior, in much the same way as does the husband who wants his wife murdered, financially compensates the contract killer.

The second error of this critic is thinking that we the present authors "...take Rothbard to hold that incitement should not be legal." We do not for a moment write in that vein. Very much to the contrary, we interpret Rothbard's clear statements to the effect that incitement should be legal to mean precisely that: to wit, that incitement should be legal. We have no quarrel with that, none whatsoever. However, this anonymous critic fails to acknowledge that Rothbard also maintains that going beyond incitement, to actively engaging in criminal activity by not only incitement but also by paying off the criminal, by having "something further to do with" the crime should not be legal. ${ }^{13}$

\section{CONCLUSION}

In the present paper, we proposed a reformulation of the libertarian theory of bribery. We argued that, contrary to what Rothbard says, the briber is not an innocent inciter to crime but rather an aider and abettor. We showed that the Rothbardian criterion for being a mere inciter is not fulfilled in the case of the briber who by paying the bribee to violate the employment contract, obviously has something further to do with the violation. Although we appreciate Rothbard's (1998) attempt to defend the briber, but not the bribee, we claim that this distinction fails, based on his brilliant distinction between incitement, which, surprisingly, should be legal, and aiding and abetting, or, having "something further to do with," the crime, which should not be legal.

\section{WORKS CITED}

Block, Walter. 2009. "Reply to Matt Mortellaro on "Block's Paradox": causation, responsibility, libertarian law, entrapment, threats, and blackmail," Libertarian Papers; http://libertarianpapers.org/2009/block-33-reply-to-matt-mortellaro-on-blocks-paradox/

Block, Walter E. 2011. "Rejoinder to Kinsella and Tinsley on Incitement, Causation, Aggression and Praxeology" Journal of Libertarian Studies; Vol. 22, pp. 641-664; http://mises.org/journals/jls/22_1/22_1_32.pdf

Block, Walter E. 2012. "Spike Lee and Incitement.” April 2; http://lewrockwell.com/block/block201.html; http://www.infowars.com/spike-lee-and-incitement/

Mortellaro, Matt. 2009. "Causation and Responsibility: A New Direction.” Libertarian Papers. Vol. 1; Article 24; http://libertarianpapers.org/2009/24-mortellaro-causation-responsibility-newdirection/

O'Neill, Ben and Walter E. Block.2013. "Inchoate crime, accessories and constructive malice in libertarian law." Libertarian Papers, Vol. 5, No. 2, pp. 219-249; http://libertarianpapers.org/articles/2013/lp-5-2-3.pdf

Rothbard, Murray N. 1998. The Ethics of Liberty. New York: New York University Press.

Received for publication: 02.03.2017

Revision received:

06.03.2017

Accepted for publication: 13.03.2017

\footnotetext{
${ }^{13}$ We do not need any "context" to make this claim

Rothbard explicitly states this, over and over again.
} 


\section{How to cite this article?}

Style - APA Sixth Edition:

Dominiak, L., \& Block, W. E. (2017, July 15). Libertarian theory of bribery and incitement: A reformulation. (Z. Čekerevac, Ed.) MEST Journal, 5(2), 95-101. doi:10.12709/mest.05.05.02.10

Style - Chicago Sixteenth Edition:

Dominiak, Lukasz, and Walter E Block. "Libertarian theory of bribery and incitement: A reformulation." Edited by Zoran Čekerevac. MEST Journal (MESTE) 5, no. 2 (July 2017): 95-101.

Style - GOST Name Sort:

Dominiak Lukasz and Block Walter E Libertarian theory of bribery and incitement: A reformulation [Journal] // MEST Journal / ed. Čekerevac Zoran. - Toronto - Belgrade : MESTE, July 15, 2017. - 2 : Vol. 5. - pp. 95-101.

Style - Harvard Anglia:

Dominiak, L. \& Block, W. E., 2017. Libertarian theory of bribery and incitement: A reformulation. MEST Journal, 15 July, 5(2), pp. 95-101.

Style - ISO 690 Numerical Reference:

Libertarian theory of bribery and incitement: A reformulation. Dominiak, Lukasz and Block, Walter E. [ed.] Zoran Čekerevac. 2, Toronto - Belgrade : MESTE, July 15, 2017, MEST Journal, Vol. 5, pp. 95101. 